\title{
Willingness To Pay Konsumen Pengguna Air Di Sub-Das Kali Dendeng - Kota Kupang
}

\author{
Jusuf Manilapai ${ }^{\text {a*, }}$ Fredrik L. Benu ${ }^{\text {a }}$, Agus A. Nalle ${ }^{\text {a }}$ \\ a Prodi Ilmu Lingkungan, Pascasarjana Universitas Nusa Cendana, Kupang, Nusa Tenggara Timur - Indonesia \\ *Email: manilapai86@gmail.com \\ Diterima (received) 13 Desember 2020; disetujui (accepted) 1 Februari 2021; tersedia secara online (available online) 1 Februari 2021
}

\begin{abstract}
Global awareness towards climate change has been a serious concern for archipelago countries due to water shortage. This problem even causes more serious life-threating phenomenon because water is one of the main resources for energy circulation. Whether change anomalies have brought about impacts on seasonal shift on several islands of Indonesia, including those in East Nusa Tenggara province. These islands experience drought. Fresh water availability for industry and domestic use in cities like Kupang has been a serious problem. This issue becomes worse in recent years due to significant increase of city population. Public responsibility to maintain natural environment and resources is therefore required. This study tries to investigate public concerns over the water shortage issue in order (1) to know to what extent public is willing to pay their consumption of fresh water provided through Sub-DAS Kali Dendeng; and (2) to analyze factors that influence the willingness of the fresh water consumers to pay for environment services provided at Sub-DAS Kali Dendeng. Quantitative approach which relies on primary and secondary data gathered through interview and field observation is applied in this study. The data were analyzed by using Dichotomous Choice CVM, Turnbull Method, and Logistic Regression to find out WTP value. The results of this analysis are described within the environmental science perspective to find out the relationship among various factors for being water consumer responsibility towards water resources preservation at Sub-DAS Kali Dendeng in Kupang. The results of the analysis show that the willingness to pay for fresh water by consumer at Kelurahan Manutapen, Mantasi dan Airmata is significantly high. They are willing to pay between Rp. 3.362 to Rp.11.328 according to WTP calculation. This amount is much higher than that determined by the city freshwater supplier company (PDAM). The facts for the reason why the consumers are willing to pay for higher amount for fresh water supply are determined by several factors; they include bidding value, consumer's level of education, consumer's income, water quality, and the amount of the family members. These factors simultaneously influence the water consumer willingness to pay for the water they consume; and this willingness factor has significantly high impacts as seen in Negelkerke R. Square value at 0,600 , or being comparable to $60 \%$; meaning that various factors of $60 \%$ in $\mathrm{Y}$ are able to explain all free variable in X. Respondents for this study are those who use fresh water supplied from Sub-DAS Kali Dendeng, and those who reside around the Sub-DAS Kali Dendeng. It is believed that there must be more citizens around the Sub-DAS Kali Dendeng, who also contribute negative impact toward the ecological environmental change, yet these individuals have no direct responsibility, and therefore the responsibility for the environmental conservation examined trough this study might not be thoroughly measured by the amount of WTP they pay.
\end{abstract}

Keywords: Water resource; WTP; Environmental conservation

\section{Abstrak}

Ancaman perubahan iklim lebih dicemaskan oleh negara-negara kepulauan karena ketersediaan air yang menjadi salah satu sumberdaya utama dalam sirkulasi energi. Anomali perubahan iklim

doi: https://doi.org/10.24843/blje.2021.v21.i01.p01

(C) 2019 by the authors; Content from this work may be used under the terms of the Creative Commons Attribution 3.0 licence. Any further distribution of this work must maintain attribution to the author(s) and the title of the work, journal citation and DOI. Published under licence by Udayana University, Indonesia. 
berimbas pada pergeseran musim di beberapa wilaya h kepulauan Indonesia termasuk Provinsi NTT yang terancam kekeringan. Ketersediaan air bersih untuk kebutuhan industri dan domestik di daerah perkotaan seperti Kota Kupang juga kian meningkat seiring pertambahan jumlah penduduk sehingga dibutuhkan tanggung jawab lingkungan dari para konsumennya. Penelitian ini bertujuan untuk; (1) Mengetahui besaran Willingness to Pay (WTP) konsumen pengguna air di Sub-DAS Kali Dendeng, (2) Menganalisis faktor-faktor yang mempengaruhi kesediaan konsumen pengguna air untuk melakukan pembayaran jasa lingkungan di Sub-DAS Kali Dendeng. Pendekatan kuantitatif dengan mengandalkan data sekunder dan primer yang terkumpulkan melalui wawancara dan observasi lapangan kemudian dianalisis menggunakan dichotomous choise CVM, Metode Tumbull dan Regresi Logistik untuk mengetahui nilai WTP. Hasil analisis menunjukan kesediaan membayar air bersih oleh konsumen pengguna air di Kelurahan Manutapen, Mantasi, dan Airmata pada Sub-DAS Kali Dendeng pada kisaran Rp 3.362 sampai Rp 11.328 sesuai hasil perhitungan WTP yang lebih tinggi dibandingkan dengan tarif yang ditetapkan oleh PDAM. Nilai WTP konsumen pengguna air di SubDAS Kali Dendeng terhadap peningkatan layanan air bersih PDAM Kota Kupang dipengaruhi oleh faktor Nilai Bid, Tingkat Pendidikan, Pendapatan, Kualitas Air dan Jumlah Anggota Rumah Tangga. Kelima faktor dimaksud secara simultan berpengaruh terhadap kesediaan membayar konsumen pengguna air yang besar pengaruhnya terlihat dari Nilai Negelkerke R-Square sebesar 0,600 atau setara dengan $60 \%$, yang artinya $60 \%$ keragaman dalam $\mathrm{Y}$ yang mampu dijelaskan oleh seluruh variabel bebas (X). Lingkupan responden adalah para pengguna jasa air bersih yang berada disekitar lingkungan ekologis Sub-DAS Kali Dendeng namun masih banyak masyarakat disekitarnya yang diduga berkontribusi terhadap perubahan ekologis sumberdaya air yang tidak memiliki keterikatan tanggung jawab terhadap dampak kerusakan lingkungannya sehingga tanggung jawab pelestarian lingkungan tidak seutuhnya terukur dari besaran WTP yang dibayarkan.

Kata Kunci: Sumberdaya Air; WTP; Pelestarian Lingkungan

\section{Pendahuluan}

Peran strategis manusia dalam upaya menjamin keberlanjutan kehidupan secara sistemik terlah berdampak terhadap perubahan iklim global yang salah satu objek perubahannya adalah air. Gerakan kesadaran untuk melestarikan alam melalui berbagai skema pelestarian seperti Reducing Emissions from Deforestation and Forest Degradation (REDD), Clean Development Mechanism (CDM), dan Payment for Environmental Services (PES) terus diupayakan berbagai Negara sebagai wujud tanggungjawab terhadap ketersediaan sumberdaya alam (Keraf, 2010). Anomali perubahan iklim berimbas pada pergeseran musim di beberapa wilayah kepulauan Indonesia termasuk Provinsi NTT yang terancam kekeringan. Ketersediaan air bersih untuk kebutuhan industri dan domestik di daerah perkotaan seperti Kota Kupang juga kian meningkat seiring pertambahan jumlah penduduk sehingga dibutuhkan tanggung jawab lingkungan dari para konsumennya.

Sumber daya air bersih yang termanfaatkan oleh masyarakat Kota Kupang mencakupi 13 mata air dan 12 sumur bor dengan kapasitas pengaliran mencapai 296,26 L/dt, dan memproyeksikan pada tahun 2030 kapasitas air bersih belum mencukupi standar rata-rata kebutuhan air bersih. Urusan air bersih di Kota Kupang bukan hanya keterbatasan sumber air dan kualitas air namun perihal polemik manajemen pengelolaan air bersih antara PDAM Tirta Lontar (Kabupaten Kupang) dengan PDAM Tirta Bening (Kota Kupang) juga menjadi penyebab ketidaktuntasan urusan air bersih bagi masyarakat Kota Kupang. Pemerintah Kota Kupang dituntut mampu memaksimalkan potensi sumber daya airnya untuk memenuhi kebutuhan air masyarakat Kota Kupang yang kedepannya diperkirakan mencapai 685.9 L/dtk pada tahun 2030 (Rugo Theodolfi dan Waangsir, 2014).

Kondisi demikian menuntut Pemerintah Kota Kupang selaku regulator harus memaksimalkan potensi sumberdaya air yang dimiliki, termasuk salah satunya adalah Sub-DAS Kali Dendeng yang melintasi 3 (tiga) kecamatan di Kota Kupang dengan kapasitas produksi 50 liter/detik. Kontribusi ekologis sumber daya air Kali Dendeng bagi masyarakat Kota Kupang maka ditimbang penting adanya langkah sistemik yang berkelanjutan dalam rangka pelestariannya dengan melibatkan masyarakat sekitar sebagai subjek sekaligus objek pelestarian lingkungan. Sisi inilah konsep jasa lingkungan menurut Suprayitno (2008), sebagai jasa yang diberikan oleh fungsi ekosistem alam maupun buatan yang nilai dan 
manfaatnya dapat dirasakan secara langsung maupun tidak langsung oleh para pemangku kepentingan (stakeholder) dalam rangka membantu memelihara dan/tau meningkatkan kualitas lingkungan dan kehidupan masyarakat dalam mewujudkan pengelolaan ekosistem secara berkelanjutan. Penelitian ini bertujuan untuk (1) Mengetahui besaran Willingness to Pay (WTP) konsumen pengguna air di Sub-DAS Kali Dendeng, (2) Menganalisis faktor-faktor yang mempengaruhi kesediaan konsumen pengguna air untuk melakukan pembayaran jasa lingkungan di Sub-DAS Kali Dendeng.

\section{Metode Penelitian}

Penelitian yang dilakukan di Sub-DAS Kali Dendeng Kota Kupang ini terfokus pada tanggung jawab lingkungan para konsumen di beberapa kelurahan seputaran lintasan Sub-DAS. Aspek metodologisnya menggunakan pendekatan kuantitatif dengan mengandalkan data sekunder dan primer yang terkumpulkan melalui wawancara dan observasi lapangan. Data dimaksud kemudian dianalisis menggunakan alat analisis dichotomous choise CVM, Metode Tumbull dan Regresi Logistik untuk mengetahui nilai WTP konsumen air bersih pada Sub-DAS Kali Dendeng. Hasilnya dideskripsikan dalam perspektif ilmu lingkungan untuk mengetahui keterkaitan antar faktor (nilai Bid, tingkat pendidikan, pendapatan, kualitas air, jumlah anggota rumah tangga, jarak ke Sub-DAS Kali Dendeng) sebagai tanggung jawab konsumen air terhadap pelestarian sumberdaya air di Sub-DAS Kali Dendeng Kota Kupang.

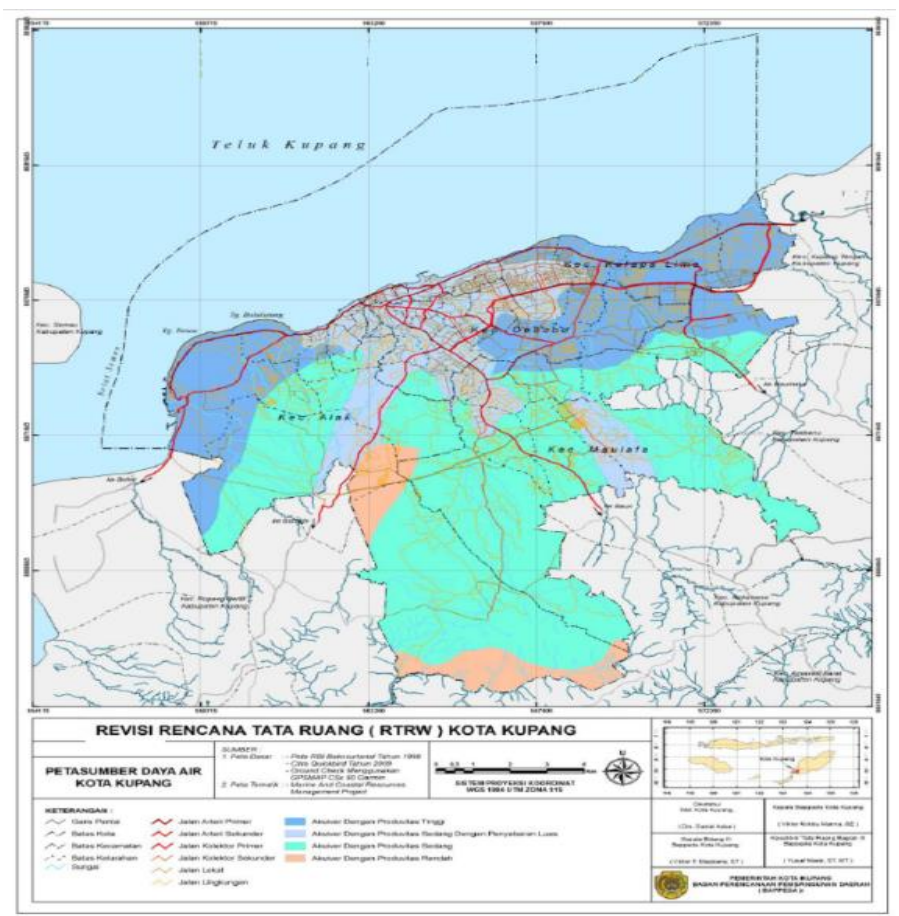

Gambar 1. Peta potensi sumber air Kota Kupang

\section{Hasil dan Pembahasan}

\subsection{Besaran WTP Konsumen Pengguna Air di Sub-DAS Kali Dendeng-Kota Kupang}

Pengujian secara individual atau parsial dapat dilakukan dengan Uji Wald, sedangkan pengujian secara simultan atau serentak dilakukan dengan menggunakan Uji Overal Model Fit/Omnibus. Tujuannya untuk mengetahui hubungan antara faktor-faktor yang mempengaruhi kesediaan konsumen pengguna air 
untuk melakukan pembayaran jasa lingkungan di Sub-DAS Kali Dendeng (nilai Bid, tingkat pendidikan, pendapatan, kualitas air, jumlah anggota rumah tangga dan jarak ke Sub-DAS Kali Dendeng) dengan kesediaan mambayar air bersih/WTP. Analis data dan pengujian terhadap masing-masing hipotesis dalam penelitian menggunakan SPSS for windows.

Tabel 1. Hasil uji koefisien regresi logistic

\begin{tabular}{lcccccc}
\hline \multicolumn{1}{c}{ Variabel } & B & S.E. & Wald & df & Sig. & Exp(B) \\
\hline NILAI Bid & -.002 & .001 & 5.424 & 1 & .020 & .998 \\
PENDIDIKAN & 1.167 & .590 & 3.914 & 1 & .048 & 3.214 \\
PENDAPATAN & .000 & .000 & .000 & 1 & .997 & 1.000 \\
KUALITAS AIR & .699 & 1.807 & .150 & 1 & .699 & 2.012 \\
Anggota RT & .309 & .286 & 1.166 & 1 & .280 & 1.362 \\
Jarak ke Kali Dendeng & -.550 & .493 & 1.248 & 1 & .264 & .577 \\
Constant & 3.686 & 2.192 & 2.828 & 1 & .093 & 39.873 \\
\hline
\end{tabular}

Analisis regresi logistik dimulai dengan uji wald untuk mengetahui pengaruh masing-masing variabel independen terhadap variabel dependen. Uji terhadap nilai Bid menunjukan bahwa nilai bid yang lebih rendah mempengaruhi konsumen pengguna air untuk bersedia membayar WTP 0,998 kali lebih besar dibandingkan dengan nilai bid yang lebih tinggi. Nilai odd ratio sebesar 3,214 menunjukkan bahwa semakin tinggi tingkat pendidikan akan meningkatkan kecenderungan konsumen pengguna air untuk bersedia membayar sebesar 3,214 kali lebih tinggi dibandingkan dengan konsumen yang tingkat pendidikannya rendah. Nilai odd ratio sebesar 1,000 menunjukkan bahwa peningkatan pendapatan konsumen pengguna air akan meningkatkan kecenderungan konsumen untuk bersedia membayar sebesar satu kali lebih tinggi dibandingkan dengan konsumen yang tidak mengalami peningkatan pendapatan.

Analisis regresi logistik terhadap faktor lainnya menunjukan bahwa nilai odd ratio sebesar 2,012 menunjukkan bahwa semakin tinggi kualitas air akan meningkatkan kecenderungan konsumen pengguna air untuk bersedia membayar sebesar dua kali kali lebih tinggi dibandingkan dengan kualitas air yang rendah. Nilai odd ratio sebesar 1,362 menunjukkan bahwa peningkatan jumlah anggota rumah tangga pengguna air akan meningkatkan kecenderungan konsumen atau rumah tangga untuk bersedia membayar sebesar satu kali lebih tinggi dibandingkan dengan konsumen yang tidak mengalami peningkatan jumlah anggota rumah tangga. Nilai odd ratio sebesar 0,577 menunjukkan bahwa jarak ke Sub-DAS kali Dendeng akan meningkatkan kecenderungan konsumen untuk bersedia membayar sebesar 0,577 kali lebih tinggi dibandingkan dengan konsumen yang memiliki jarak yang lebih jauh dari Sub-DAS Kali Dendeng.

Selanjutnya uji keseluruhan model (Overall Model Fit) untuk menguji variabel independen di dalam regresi logistic secara simultan mempengaruhi variabel dependen. Nilai chi square hitung senilai 29,336, kemudian chi square tabel yang didapatkan senilai 12,5915 dan 29,336>12,5915, nilai sig. sebesar 0,000 dan ini lebih kecil dari 0,05 maka dapat disimpulkan bahwa Nilai Bid, Tingkat Pendidikan, Pendapatan, Kualitas Air dan Jumlah Anggota Rumah Tangga, Jarak ke Sub-DAS Kali Dendeng secara simultan berpengaruh terhadap kesediaan membayar konsumen pengguna air.

Koefisien determinasi yang digunakan untuk mengetahui seberapa besar variabilitas variabel dependen sehingga variabel Nilai Bid, Tingkat Pendidikan, Pendapatan, Kualitas, Jumlah Anggota Rumah Tangga, dan Jarak ke Sub-DAS kali Degeng di dalam penelitian ini memiliki kemampuan dalam menjelaskan variabel kesediaan membayar konsumen pengguna air sebesar $60 \%$ dan $40 \%$ dijelaskan oleh variabel faktor lainnya yang tidak diambil oleh peneliti. nilai Chi-square hitung < Chi square tabel, maka model dapat disimpulkan mampu memprediksi nilai observasinya atau dapat dikatakan model dapat diterima karena cocok dengan data observasinya. Kekuatan prediksinya mencapai kekuatan prediksi atau ketepatan model dalam mengklasifikasikan observasinya adalah sebesar $86 \%$. Hasil uji regresi logistiknya kemudian menghasilkan persamaan regresi berikut: 
Analisis Willingness to Pay (WTP) masyarakat terhadap air bersih digunakan untuk mengetahui tingkat kemampuan membayar masyarakat untuk mendapatkan air bersih dimana tingkatan harga yang ditawarkan merupakan harga air yang ingin dibayar oleh masyarakat per meter kubiknya. Hasil nilai Bid menggunakan metode dichotomous choice CVM yaitu persentase distribusi responden yang menjawab setuju pada nilai bid $\mathrm{Rp} 4.000$ [92\%] dan jawaban tidak adalah 8\%. Nilai bid Rp 5.000, terdapat 83\% menjawab setuju dan $17 \%$ menjawab tidak setuju, nilai bid Rp 7.500 menjawab tidak setuju $69 \%$ dan $31 \%$ menjawab setuju, serta nilai bid Rp. 9.000 jawaban tidak setuju [85\%] dan setuju hanya sekitar 15\%.

Perhitungan Nilai WTP menggunakan metode turnbull menyimpulkan bahwa apabila bid yang ditawarkan semakin tinggi maka jumlah orang yang tidak mau membayar akan semakin meningkat. Proporsi WTP terhadap pendapatan rumah tangga adalah sebesar $0,29 \%$ yang menggambarkan proporsi dari nilai WTP yang dibayarkan konsumen untuk air bersih per meter kubiknya terhadap pendapatan rumah tangga.

Perbandingan hasil WTP dengan tarif PDAM Kota Kupang menunjukan bahwa konsumen pengguna air pada Kelurahan Manutapen, Mantasi, dan Airmata di Sub-DAS Kali Dendeng termasuk kepada golongan pelanggan 'Rumah Tangga A' dengan pemakaian air lebih dari $10 \mathrm{~m}^{3}$ sehingga tarif PDAM yang dikenakan adalah Rp 6.000/ $\mathrm{m}^{3}$ (Kepwalkot Kupang Nomor 132 tahun 2013). Hasil expected atau nilai harapan WTP yang diperoleh, kesediaan membayar air bersih oleh konsumen pengguna air di Kelurahan Manutapen, Mantasi, dan Airmata pada Sub-DAS Kali Dendeng berada pada kisaran Rp 3.362 sampai Rp 11.328 sesuai dengan hasil perhitungan WTP sehingga WTP konsumen pengguna terhadap air bersih lebih tinggi dibandingkan dengan tarif yang ditetapkan oleh PDAM. Selisih dari nilai WTP dan tarif PDAM menunjukkan nilai-nilai yang tidak diperoleh dari pasar atau nilai non-market seperti kenyamanan apabila menggunakan air PDAM sehingga masyarakat tidak kuatir kesulitan air pada saat kemarau, dari segi kesehatan dimana air PDAM kualitasnya lebih terjamin, dari nilai keberadaan air sehingga kontinuitas air dapat terjaga untuk masa kini dan masa yang akan datang, dan dari nilai konservasi air.

\subsection{Faktor yang Mempengaruhi WTP Konsumen terhadap Air Bersih}

Variabel bid berpengaruh penting karena nilai bid menentukan apakah masyarakat bersedia atau tidak membayar nilai bid yang ditawarkan. Koefisian bertanda positif (+) yang berarti variabel bid berpengaruh positif, semakin rendah nilai bid maka semakin besar peluang menjawab setuju. Hasil uji statistik memperlihatkan nilai wald sebesar 5,424 (sig. 0,020). Nilai signifikansi 0,020 lebih kecil dari tingkat signifikansi sebesar 0,05 . Dimana nilai odd ratio variabel nilai bid adalah 0,998 , ini berarti nilai bid yang lebih rendah mempengaruhi konsumen pengguna air untuk bersedia membayar WTP 0,998 kali lebih besar dibandingkan dengan nilai bid yang lebih tinggi.

Jumlah anggota keluarga mencakup tanggungan keluarga inti maupun bukan inti yang tinggal didalam rumah dan ditanggung oleh responden. Hasil uji statistik memperlihatkan nilai wald sebesar 1,166 (sig. 0,280). Nilai signifikansi 0,280 lebih besar dari tingkat signifikansi sebesar 0,05 maka simpulannya adalah hipotesis ditolak yaitu variabel jumlah anggota rumah tangga tidak berpengaruh signifikan terhadap kesediaan membayar konsumen pengguna air. Sementara faktor tingkat pendidikan yang teridentifikasi dari nilai odd ratio sebesar 3,214 menunjukkan bahwa semakin tinggi tingkat pendidikan akan meningkatkan kecenderungan konsumen pengguna air untuk bersedia membayar sebesar tiga kali lebih tinggi dibandingkan dengan konsumen yang tingkat pendidikannya rendah. Faktor pendapatan menunjukan bahwa Nilai signifikansi 0,997 lebih besar dari tingkat signifikansi sebesar 0,05. Nilai odds ratio variabel pendapatan adalah 1,000 yang berarti tingkat pendapatan yang lebih tinggi mempengaruhi responden untuk bersedia membayar WTP satu kali lebih besar dibandingkan den gan responden yang pendapatannya lebih rendah. 
Faktor kualitas air diperoleh Nilai odd ratio sebesar 2,012 menunjukkan bahwa semakin tinggi kualitas air akan meningkatkan kecenderungan konsumen pengguna air untuk bersedia membayar sebesar dua kali lebih tinggi dibandingkan dengan kualitas air yang rendah. Faktor terakhir yaitu jarak menunjukan Nilai odd ratio sebesar 0,577 menunjukkan bahwa semakin dekat jarak ke Sub-DAS Kali Dendeng akan meningkatkan kecenderungan konsumen pengguna air untuk bersedia membayar sebesar 0,577 kali lebih tinggi dibandingkan dengan jarak ke Sub-DAS Kali Dendeng yang lebih dekat.

\section{Simpulan dan Saran}

Simpulan yang diajukan dari permasalahan dan pembahasan adalah nilai kesediaan konsumen pengguna air menggunakan metode turnbull yang hasil expected WTP-nya sebesar Rp 7.345 sehingga jika dibandingkan dengan tarif air PDAM Kota Kupang maka konsumen pengguna air pada Kelurahan Manutapen, Mantasi, dan Airmata di Sub-DAS kali Dendeng termasuk kepada golongan pelanggan Rumah Tangga A dengan pemakaian air lebih dari $10 \mathrm{~m}^{3}$ sehingga tarif PDAM yang dikenakan adalah $\mathrm{Rp}$ $6.000 / \mathrm{m}^{3}$. Nilai harapan WTP yang diperoleh kesediaan membayar air bersih oleh konsumen pengguna air di Kelurahan Manutapen, Mantasi, dan Airmata pada Sub-DAS Kali Dendeng berada pada kisaran Rp 3.362 sampai Rp 11.328 sesuai dengan hasil perhitungan WTP. WTP konsumen pengguna terhadap air bersih lebih tinggi dibandingkan dengan tarif yang ditetapkan oleh PDAM. Selisih dari nilai WTP dan tarif PDAM menunjukkan nilai-nilai yang tidak diperoleh dari pasar atau nilai non-market seperti kenyamanan apabila menggunakan air PDAM sehingga masyarakat tidak khawatir kesulitan air pada saat kemarau, dari segi kesehatan dimana air PDAM kualitasnya lebih terjamin, dari nilai keberadaan air sehingga kontinuitas air dapat terjaga untuk masa kini dan masa yang akan datang, dan dari nilai konservasi air.

Faktor-faktor yang mempengaruhi WTP konsumen pengguna air di Sub-DAS Kali Dendeng terhadap peningkatan layanan air bersih PDAM Kota Kupang adalah Nilai Bid, Tingkat Pendidikan, Pendapatan, Kualitas Air dan Jumlah Anggota Rumah Tangga, dan Jarak. Kelima faktor tersebut diketahui secara simultan berpengaruh terhadap kesediaan membayar konsumen pengguna air. Dimana besar pengaruh dapat dilihat dari Nilai Negelkerke R Square sebesar 0,600 atau setara dengan 60\%, yang artinya $60 \%$ keragaman dalam Y yang mampu dijelaskan oleh seluruh variabel bebas (X). Lingkupan responden adalah para pengguna jasa air bersih yang berada disekitar lingkungan ekologis Sub-DAS Kali Dendeng namun masih banyak masyarakat disekitarnya yang diduga berkontribusi terhadap perubahan ekologis sumberdaya air yang tidak memiliki keterikatan tanggung jawab terhadap dampak kerusakan lingkungannya sehingga tanggung jawab pelestarian lingkungan tidak seutuhnya terukur dari besaran WTB yang dibayarkan.

Adapun saran yang dapat diberikan, hasil WTP yang diperoleh dapat menjadi acuan untuk pihak PDAM Kota Kupang yang berperan sebagai operator untuk lebih mengoptimal pengolahan fisik water treatment plant di Sub-DAS Kali Dendeng sehingga kualitas air yang dihasilkan sesuai dengan standar dan keinginan konsumen pengguna air untuk dikonsumsi. Penetapan tarif yang diberlakukan PDAM Kota Kupang cenderung masih undervalue. Seharusnya dimasukkan pula nilai-nilai yang tidak diperoleh dari pasar atau nilai nonmarket dari air seperti nilai keberadaan dan nilai konservasi. Nilai ini dapat dilihat dari hasil expected WTP yang didapatkan, sehingga direkomendasikan untuk menjadi pertimbangan dalam penetapan tarif PDAM. Penelitian selanjutnya mengenai analisis WTP menggunakan dichotomous choice CVM dapat menggunakan sampel yang lebih banyak dan nilai bid dengan range yang lebih luas. Analisis WTP juga dapat menggunakan metode choice modeling atau choice experiment.

\section{Daftar Pustaka}


A. Sandhyavitri, N.R. Putri, M. Fauzi, dan S. Sitikno. (2016). Analisis Kesediaan Masyarakat untuk Membayar (Willingness to Pay) Biaya Pengadaan Air Bersih (PDAM) di Kota Pekanbaru. Jurnal Teknik Sipil dan Perencanaan, 18(2).

Agus Widarjono. (2010). Analisis Statistika Multivariat Terapan. (Edisi pertama). Yogyakarta: UPP STIM YKPN

Badan Pusat Statistik Kota Kupang. (2018). Kota Kupang dalam Angka. Kupang: Badan Pusat Statistik Kota Kupang.

Bani, A.( 2020). Willingness To Pay (WTP) for environmental services of well water sources in Kupang City. Jurnal Pengelolaan Sumberdaya Alam dan Lingkungan, 10(2)

Creswell, J. W. (2010). Research design: pendekatan kualitatif, kuantitatif, dan mixed. Yogjakarta: PT Pustaka Pelajar

Danish International Development Agency (DANIDA)-KLH. (2011). Environmental Support Programme Phase 2.

de Rozari, Philiphi. (2017). Kajian Strategi Pengendalian Pencemaran Sub Daerah Aliran Sungai (DAS) Kali Dendeng Kota Kupang. Jurnal Inovasi Kebijakan, 2(1)

Fauzi, A. (2006). Ekonomi Sumber Daya Alam dan Lingkungan. Teori dan Aplikasi. Jakarta: PT Gramedia Pustaka Utama.

Flint, R.W. (2003). The Sustainable Development of Water Resources. http://www.sustainabledevelopmentsolutions.com, [diakses 10-7-2019]

Ghozali, Imam. (2012). Aplikasi Analisis Multivariate dengan Program IBM SPSS 20. Semarang: UNDIP.

IPB. (2013). Valuasi Ekonomi dan Penilaian Kerusakan Sumberdaya Alam dan Lingkungan. Bogor: IPB Press.

IPB. (n.d.). Analisis Willingness To Pay Masyarakat terhadap Pembayaran Jasa Lingkungan Mata Air Cirahab (Desa Curug Goong, Kecamatan Padarincang, Kabupaten Serang, Banten), URL https://repository.ipb.ac.id/handle/123456789/11357, [diakses: 8.1.19].

Keraf, A. S. (2010). Etika Lingkungan Hidup. Jakarta: Buku Kompas

Khopiatuziadah. (2015). Konsep Imbal Jasa Lingkungan Dalam Penyelenggaraan Konservasi Tanah dan Air. Jurnal Rechts Vinding Online, 1, Juni 2015.

Landell-Mills N, Porras IT. (2002). Silver Bullet or Fools' Gold? A Global Review of Markets for Forest Environmental Services and Their Impact on The Poor. London: International Institute for Environmental and Development.

Loucks, D.P., 2000. Sustainable Water Resources Management. Water International, 25, 3-10. https://doi.org/10.1080/02508060008686793

Lundin, T., Falk, R.H., Felton, C. (2002). Accelerated weathering of natural fiber-thermoplastic composites: effects of ultraviolet exposure on bending strength and stiffness. Sixth International Conference on Woodfiber-Plastic Composites : May 15-16, 2001 ... Madison, Wisconsin. Madison, WI : Forest Products Society, c2002: ISBN: 0892529181: pages 87-93.

Milne, A., Chervier, S.; C. (n.d.). A Review of payments for environmental services (PES) experiences in Cambodia. Center for International Forestry Research. URL https://www.cifor.org/library/5070/ [diakses: 7.25.19].

Mumu N. (2017). Air Minum Kota Kupang Uncover. Jakarta: Rafikatama.

Myrick, A. F. (2014). The measurement Of Environmental And Resource Values. Theory and Methods. (Third Editon). Washington, D.C : Resources for the future.

Napitupulu, Dinda Febrima. (2013). Kajian Mekanisme Pembayaran Jasa Lingkungan Penyediaan Sumberdaya Air (Studi Kasus di Kabupaten Lombok Barat dan Kota Mataram, Nusa Tenggara Barat). Jurnal Ilmu Lingkungan, 11(2), 2013. 
Pagiola, S, Agustin Arcenas, and Gunars Platais. (2005). Can Payments for Environmental Services Help Reduce Poverty? An Exploration of the Issues and the Evidence to Date from Latin America. World Development, 33(2), 237-253

Panayotou, T. (1994). Economy and Ecology in Sustainable Development. Jakarta: Gramedia Pustaka Utama in cooperation with SPES Foundation

Pemerintah Kota Kupang. (2015). Rencana Induk Sistem Penyediaan Air Minum Kota Kupang Tahun 2015 - 2035. Kupang: Pemerintah Kota Kupang

Pemerintah Kota Kupang. (2017). Review Rencana Terpadu dan Program Investasi Infrastruktur Jangka Menengah Kota Kupang tahun 2017-2021. Kupang: Pemerintah Kota Kupang

Republik Indonesia. (2019). Undang-undang Nomor 17 tahun 2019, tentang Sumber Daya Air. Jakarta: Republik Indonesia

Salim, E. (2010). Pembangunan Berkelanjutan. Jakarta: Kepustakaan Populer Gramedia

Syamsir Nur dan Arifin Arifin. (2019). Analisis Kesediaan Masyarakat dalam Membayar (Willingness To Pay) Tarif PDAM Kota Kendari. Mega Aktiva: Jurnal Ekonomi dan Manajemen, 8(2)

The Centre for Social and Economics Research on the Global Environment. (1994). Economic values and the environment in the development world. Nairobi: A Report to the UNEP 